\title{
Rancang Bangun Aplikasi EXAM dengan Metode Analisis Butir Soal
}

\author{
Yudho Yudhanto, Anjelika Margareta \\ Program Studi D3 Teknik Informatika, Sekolah Vokasi, Universitas Sebelas Maret \\ Email : yuda@mipa.uns.ac.id, anjelikamargareta37@gmail.com
}

\section{Info Artikel}

\section{Kata Kunci :}

analisis butir soal, tingkat kesulitan, daya pembeda, distraktor, guru, peserta ujian

\section{Keywords : item analysis, difficulty levels, distinguishing power, distractors, teacher, examinees \\ Tanggal Artikel \\ Dikirim : 2 April 2021 \\ Diterima : 30 Mei 2021}

\section{Abstrak}

Tujuan dari sistem yang akan dibuat ini adalah untuk memudahkan guru mengetahui tingkat kesulitan soal yang dikerjakan peserta ujian, serta memudahkan peserta ujian melihat informasi hasil ujian lulus atau tidak berdasarkan nilai yang diperoleh sebagai acuan untuk mengerjakan soal ujian ulang. Metode yang digunakan dalam penelitian ini adalah analisis butir soal kuantatif. Penelaahan soal secara kuantitatif adalah penelaahan butir soal didasarkan pada bukti empirik. Tingkat kesukaran dinyatakan dalam indeks kesukaran (dificulty index), adalah angka yang menunjukkan proporsi siswa yang menjawab benar soal tersebut. Semakin besar indeks tingkat kesukaran yang diperoleh dan hasil hitungan, berarti semakin mudah soal itu. Semakin tinggi koefisien daya pembeda suatu butir soal, semakin mampu butir soal tersebut membedakan antara peerta didik yang menguasai kompetensi dengan peserta didik yang kurang menguasai kompetensi. Penelitian ini akan diawali dengan membuat proses bisnis dari pembuatan soal ujian hingga hasil akhir nilai ujian. Sebelum membuat perancangan aplikasi diperlukan tabel Kebutuhan Fungsional Sistem. Selanjutnya, dalam perancangan aplikasi yang pertama yaitu Usecase Diagram dan Skenario Usecase. Setelah itu membuat Class Diagram dan Sequence Diagram. Setelah perancangan selesai, lalu membuat rancangan database dengan ERD (Entity Relationship Diagram), Relasi Antar Tabel, dan Perancangan Tabel. Kemudian membuat desain User Interface. Setelah itu, sistem diuji dengan metode Blackbox. Hasil penelitian pada tugas akhir Rancang Bangun Aplikasi Exam Dengan Metode Analisis Butir Soal adalah sistem yang berasal dari perancangan aplikasi dan perancangan database yang telah diimplementasikan untuk menganalisis butir soal ujian berdasarkan bobot yang telah ditentukan pada setiap opsi jawaban.

\section{Abstarct}

The purpose of the system that will be created is to make it easier for teachers to find out the level of difficulty of the questions done by the examinees, and to make it easier for the examinees to see information on the results of the graduated exam or not based on the scores obtained as a reference for working on retest questions. The method used in this research is quantitative item analysis. Quantitative review of questions is a review of items based on empirical evidence. Difficulty level is expressed in the difficulty index, is a number that shows the proportion of students who answered the problem correctly. The greater the difficulty level index obtained and the results of the calculation, the easier the problem is. The higher the coefficient of distinguishing power of an item, the more able the item is to distinguish between students who master competencies and students who lack competency. This research will begin by making a business process from making exam questions to the final results of the exam scores. Before making an application design, a System Functional Requirement table is needed. Next, in designing the first application, the Usecase Diagram and the Usecase Scenario. After that make a Class Diagram and Sequence Diagram. After the design is complete, then create a database design with ERD (Entity Relationship Diagram), Relationships Between Tables, and Table Design. Then create a User Interface Design. After that, the system is tested by the Blackbox Method. The results of the research in the final project Design and Application Development Exam with Item Analysis Method Problem is a system derived from the application design and database design that has been implemented to analyze the test items based on the weight that has been determined on each answer option. 


\section{PENDAHULUAN}

Ujian merupakan salah satu cara untuk mengevaluasi proses belajar. Dalam dunia pendidikan ujian dimaksudkan untuk mengukur taraf pencapaian suatu tujuan pengajaran oleh siswa atau mahasiswa sebagai peserta didik, sehingga siswa atau mahasiswa dapat mengetahui tingkat kemampuannya dalam memahami bidang studi yang sedang ditempuh.

Teknologi komunikasi dan elektronik sudah berkembang sedemikian pesat. Komunikasi semakin tidak terbatas semenjak terciptanya jaringan internet. Pada tahun 2019, di Indonesia diproyeksikan pengguna internet tembus 175 juta (sekitar 65,3\%) dari total jumlah penduduk 268 juta [1]. Perkembangan teknologi komputer yang sudah sangat maju memberikan manfaat yang cukup besar disegala bidang. Sehingga menyebabkan bidang pendidikan juga turut mengalami peningkatan dalam hal kualitas, kecepatan, kepraktisan, dan juga kemudahan. Ujian konvensional pun bergeser ke arah komputerisasi, salah satunya dengan adanya ujian online. Selain itu, ujian juga berkembang dengan menggunakan metode analisis butir soal.

Metode analisis butir soal merupakan analisis yang dapat dilakukan apabila suatu tes telah dilaksanakan dan hasil jawaban terhadap butir-butir soal telah kita peroleh. Analisis butir soal adalah suatu kegiatan analisis untuk menentukan tingkat kebaikan butir-butir soal yang terdapat dalam suatu tes sehingga informasi yang dihasilkan dapat kita pergunakan untuk memperbaiki butir soal dan tes tersebut.

Identifikasi terhadap setiap butir item soal dilakukan dengan harapan akan menghasilkan berbagai informasi berharga, yang pada dasarnya akan merupakan umpan balik (feedback) guna melakukan perbaikan, pembenahan, dan penyempurnaan kembali terhadap butir-butir soal, sehingga pada masa-masa yang akan yang akan datang tes hasil belajar yang disusun atau dirancang oleh guru itu betul-betul dapat menjalankan fungsinya sebagai alat pengukur hasil belajar yang memiliki kualitas yang tinggi.

Dalam penelitian "Rancang Bangun Aplikasi Ujian Online Berbasis Web" telah dilakukan oleh Anggy Trisnawan Putra dari Program Studi IImu Komputer, Fakultas Matematika dan IImu Pengetahuan Alam, Universitas Negeri Semarang yang merupakan penggunaan komputer sebagai alat bantu adalah salah satu daya tarik yang menyebabkan semakin maraknya tes sejenis [2]. Dapat disimpulkan bahwa peserta tes dapat mengetahui hasilnya secara langsung, panitia atau penyelenggara tes juga dapat mendapatkan data nilai secara instan setelah tes selesai dilakukan, tidak perlu ada koreksi manual ataupun penggunaan scanner untuk membaca lembar jawab. Namun, akses ke perangkat/infrastruktur tes berbasis komputer ini masih terbatas. Pengadaan hardware dan software pendukung untuk keperluan ini tergolong cukup mahal. Oleh karena itu, penelitian ini bermaksud untuk membuat rancang bangun aplikasi ujian online berbasis web untuk selanjutnya dapat digunakan secara luas oleh masyarakat.

Penelitian kedua yaitu "Rancang Bangun Program Analisis Butir Soal Pilihan Ganda Sebagai Pendukung Proses Evaluasi Pembelajaran" telah dilakukan oleh Wisnu Wardoyo dan Eko Suprapto dari Program Studi Teknik Elektro, Fakultas Teknik, Universitas Negeri Semarang yang merupakan Research and Development melalui tahap analisis masalah, analisis kebutuhan, desain software, validasi desain, revisi desain, uji pakar, revisi 1, uji terbatas, revisi 2 , uji diperluas dan revisi 3 [3]. Dapat disimpulkan bahwa hasil penelitian menunjukkan bahwa perangkat lunak yang dikembangkan layak digunakan menganalisis butir soal pilihan ganda dan teruji sebagai sebuah perangkat lunak berdasarkan isi, tampilan, navigasi, keandalan dan kebermanfaatan perangkat lunak.

Penelitian ketiga yaitu "Rancang Bangun Aplikasi Ujian Online Untuk Siswa Smp Menggunakan Framework Laravel (Studi Kasus : SMP Negeri 4 Cikalongkulon)" telah dilakukan oleh Muhammad Dwika llyas Ruhyat dari Program Studi Teknik Informatika, Fakultas Teknik, Universitas Pasundan Bandung untuk menyelesaikan masalah pemberian soal yang lebih efisien dengan memanfaatkan teknologi [4]. Dapat disimpulkan bahwa membangun aplikasi ujian online berbasis web dapat dilakukan dengan banyak cara salah satunya yaitu menggunakan framework yang memiliki keuntungan dan kemudahan bagi developer yang akan membangun suatu aplikasi berbasis website. Untuk saat ini Framework PHP yang sedang populer yaitu Framework Laravel. Framework laravel menduduki peringkat pertama sebagai pengguna framework PHP terbanyak di seluruh dunia melebihi Framework Symphony dan Framework Codelgneter. Framework Laravel untuk saat ini banyak digunakan oleh developer baik dari luar ataupun dari dalam negeri, selain itu karena aplikasi ujian online ini dapat menyatu dengan aplikasi akademik maka akan lebih mudah dalam kerjasama tim karena dalam hal database, framework laravel memberikan fitur migration dan migrate untuk pembuatan tabel database tanpa harus masuk ke database secara langsung dan tanpa harus mengirim database ke setiap programmer ketika ada tambahan atau perubahan table, field, atau record pada database.

Penelitian keempat yaitu "Perancangan Aplikasi Computer Based Test (Cbt) Berbasis Web (Studi Kasus Di SMP Negeri 2 Kuta - Badung)" telah dilakukan oleh Dewa Ayu Sri Agustina dari Program Studi Teknik Informatika, Fakultas 
IImu Kesehatan Sains dan Teknologi, Universitas Dhayana Pura Bali untuk mempermmudah dalam melaksanakan kegiatan ujian dan menghemat waktu koreksi ujian sehingga efisiensi dan efektivitas [5]. Dapat disimpulkan bahwa cara untuk membuat proses pelaksanaan ujian online lebih mudah dan efisien, bermanfaat bagi guru dan siswa dengan memanfaatkan kemajuan teknologi komputer dengan memaksimalkan ketersediaan sarana prasarana yang ada di SMP Negeri 2 Kuta yang sudah mempunyai laboratorium komputer yang memadai, dimana di laboratorium SMP Negeri 2 Kuta memiliki sekitar 20 komputer. Hasil dari proses ujian dapat diterima oleh siswa dan guru secara langsung dengan menggunakan sistem online.

Penelitian kelima yaitu "Sistem Informasi Ujian Mandiri Online Berbasis Web Di SMP Negeri 1 Srandakan" telah dilakukan oleh Endri Rahmawanto dari Program Studi Teknik Informatika, Fakultas Teknologi Industri, Universitas Ahmad Dahlan Yogyakarta yang menerapkan aplikasi ujian mandiri online berbasis web sebagai pendukung untuk kegiatan belajar mengajar [6]. Dapat disimpulkan bahwa sistem ini mampu memberikan hasil nilai ujian secara langsung kepada siswa setelah selesai ujian. Sistem ini dapat memberikan hasil perangkingan siswa berdasarkan mata pelajaran yang telah berhasil diujikan. Hasil dari uji coba yang dilakukan oleh beberapa guru dan siswa smp menunjukkan bahwa aplikasi ini layak dan dapat digunakan untuk menunjang proses belajar mengajar di SMP Negeri 1 Srandakan.

Berdasarkan kelima tinjauan pustaka tersebut dapat disimpulkan bahwa persamaan dari kelima tinjauan diatas dengan aplikasi penulis adalah sama-sama merupakan sistem ujian online yang dibedakan berdasarkan kebutuhan user. Untuk kalangan pelajar dapat dibuat suatu aplikasi yang berfungsi untuk melakukan ujian secara online, sehingga aplikasi tersebut dapat membantu untuk proses pembelajaran yang lebih efisien dengan memanfaatkan teknologi. Perbedaan dari aplikasi yang penulis buat dibandingkan dengan kelima tinjauan diatas adalah aplikasi ujian online memiliki kelebihan fitur yaitu dengan penggunaan metode analisis butir soal yang berfungsi untuk menganalisis butir soal ujian berdasarkan bobot yang telah ditentukan pada setiap opsi jawaban.

\section{METODE PENELITIAN}

Metodologi penelitian yang dilakukan pada penelitian ini menggunakan metodologi penelitian prototype dapat dilihat pada gambar 1 .

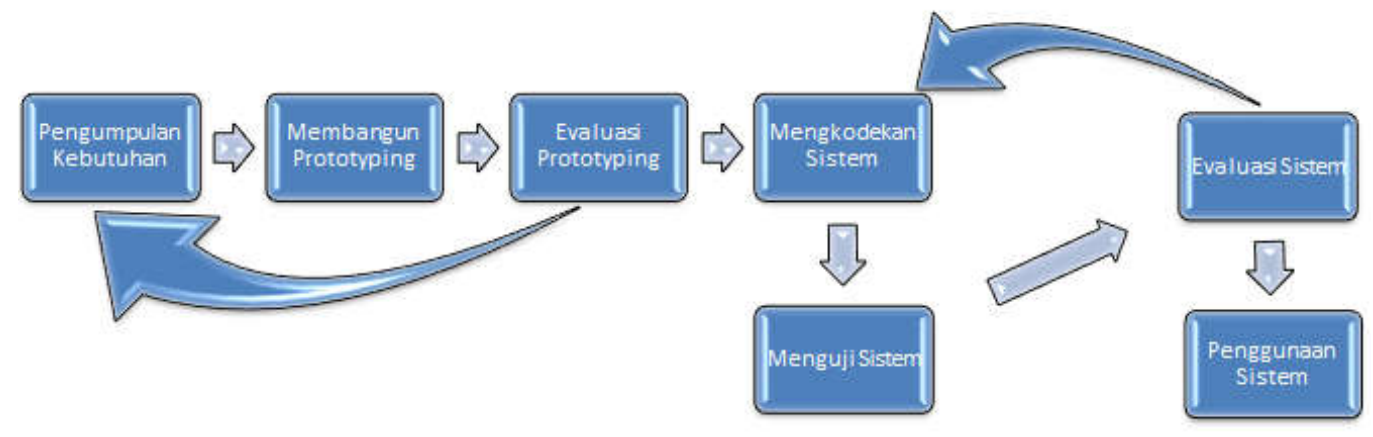

Gambar 1. Metodologi Penelitian Prototype

1. Pengumpulan Kebutuhan

Pelanggan dan pengembang bersama-sama mendefinisikan format seluruh perangkat lunak, mengidentifikasikan semua kebutuhan, dan garis besar sistem yang akan dibuat.

2. Membangun Prototyping

Membangun prototyping dengan membuat perancangan sementara yang berfokus pada penyajian kepada pelanggan (misalnya dengan membuat input dan format output).

3. Evaluasi Protoptyping

Evaluasi ini dilakukan oleh pelanggan apakah prototyping yang sudah dibangun sudah sesuai dengan keinginan pelanggan. Jika sudah sesuai maka langkah $d$ akan diambil. Jika tidak prototyping direvisi dengan mengulang langkah 1, 2, dan 3.

4. Mengkodekan Sistem

Dalam tahap ini prototyping yang sudah di sepakati diterjemahkan ke dalam bahasa pemrograman yang sesuai.

5. Menguji Sistem 
Setelah sistem sudah menjadi suatu perangkat lunak yang siap pakai, harus dites dahulu sebelum digunakan.

Pengujian ini dilakukan dengan whitebox, blackbox, basis path, pengujian arsitektur dan lain-lain.

6. Evaluasi Sistem

Pelanggan mengevaluasi apakah sistem yang sudah jadi sudah sesuai dengan yang diharapkan. Jika ya, langkah g dilakukan; jika tidak, ulangi langkah 4 dan 5.

7. Menggunakan Sistem

Perangkat lunak yang telah diuji dan diterima pelanggan siap untuk digunakan.

\section{HASIL DAN PEMBAHASAN}

Kebutuhan fungsional digunakan untuk menentukan proses-proses fungsionalitas dari aplikasi yang dilakukan oleh aktor yang memiliki akses terhadap proses sistem. Kebutuhan fungsional teserbut dapat dilihat pada tabel 1.

Tabel 1. Kebutuhan Fungsional Sistem

\begin{tabular}{|c|c|c|c|}
\hline Kode & Kebutuhan Fungsional & Aktor & Depedensi \\
\hline FR01 & Menampilkan dashboard admin & Admin & \\
\hline FR02 & Menampilkan data kategori ujian & Admin, Guru & \\
\hline FR03 & Menambah kategori ujian baru & Admin, Guru & FR02 \\
\hline FR04 & Mengubah data kategori ujian & Admin, Guru & FR03 \\
\hline FR05 & Menghapus data kategori ujian & Admin, Guru & FR03 \\
\hline FR06 & Mengaktifkan kategori ujian & Admin & FR03 \\
\hline FR07 & Menonaktifkan kategori ujian & Admin & FR03 \\
\hline FR08 & Menampilkan data soal ujian & Admin, Guru & FR02 \\
\hline FR09 & Menambah soal baru & Admin, Guru & FR08 \\
\hline FR10 & Mengubah data soal ujian & Admin, Guru & FR09 \\
\hline FR11 & Menghapus data soal ujian & Admin, Guru & FR09 \\
\hline FR12 & Mengaktifkan soal ujian & Admin & FR09 \\
\hline FR13 & Menonaktifkan soal ujian & Admin & FR09 \\
\hline FR14 & Menampilkan detail soal ujian & Admin & FR09 \\
\hline FR15 & Menampilkan data guru & Admin, Kepala Sekolah & \\
\hline FR16 & Menambah data guru & Admin & FR15 \\
\hline FR17 & Mengubah data guru & Admin & FR15 \\
\hline FR18 & Menghapus data guru & Admin & FR15 \\
\hline FR19 & Menampilkan data peserta ujian & Admin & \\
\hline FR20 & Menambah data peserta ujian & Admin & FR19 \\
\hline FR21 & Mengubah data peserta ujian & Admin, Peserta & FR19 \\
\hline FR22 & Menghapus data peserta ujian & Admin & FR19 \\
\hline FR23 & $\begin{array}{l}\text { Menampilkan data peserta ujian dengan } \\
\text { filter }\end{array}$ & Admin & FR19 \\
\hline FR24 & Memberi bobot nilai perjawaban & Guru & FR09 \\
\hline FR25 & Memanajemen durasi ujian & Guru & FR09 \\
\hline FR26 & $\begin{array}{l}\text { Mengatur mulainya pengerjaan soal } \\
\text { ujian }\end{array}$ & Guru & FR09 \\
\hline FR27 & $\begin{array}{l}\text { Menampilkan jumlah kesempatan } \\
\text { mengerjakan }\end{array}$ & Guru & \\
\hline FR28 & Menampilkan dashboard peserta & Peserta Ujian & \\
\hline FR29 & Menampilkan soal yang diaktifkan & Peserta Ujian & FR12 \\
\hline FR30 & Memilih kategori ujian & Peserta Ujian & FR06 \\
\hline FR31 & Memilih soal ujian & Peserta Ujian & FR29 \\
\hline FR32 & Menampilkan soal ujian & Peserta Ujian & FR31 \\
\hline FR33 & $\begin{array}{l}\text { Merekam hasil jawaban ujian ke dalam } \\
\text { database }\end{array}$ & Peserta Ujian & \\
\hline
\end{tabular}




\begin{tabular}{clcc}
\hline FR34 & $\begin{array}{l}\text { Melakukan penilaian jawaban peserta } \\
\text { ujian }\end{array}$ & Peserta Ujian & FR24 \\
\hline FR35 & $\begin{array}{l}\text { Mengatur tanggal pengumuman nilai } \\
\text { ujian }\end{array}$ & Kepala Sekolah & FR34 \\
\hline FR36 & Menampilkan nilai peserta ujian & Peserta Ujian & FR35 \\
\hline FR37 & Menampilkan hasil ujian dengan grafik & $\begin{array}{l}\text { Admin, Guru, Peserta } \\
\text { Ujian, Kepala Sekolah }\end{array}$ & \\
\hline FR38 & Menampilkan histori nilai ujian & $\begin{array}{l}\text { Admin, Guru, Peserta } \\
\text { Ujian, Kepala Sekolah }\end{array}$ & \\
\hline
\end{tabular}

Usecase Diagram menunjukkan hubungan fungsi-fungsi dalam sistem seperti yang sudah dijelaskan pada kebutuhan fungsional. Usecase Diagram tersebut dapat dilihat pada gambar 2.

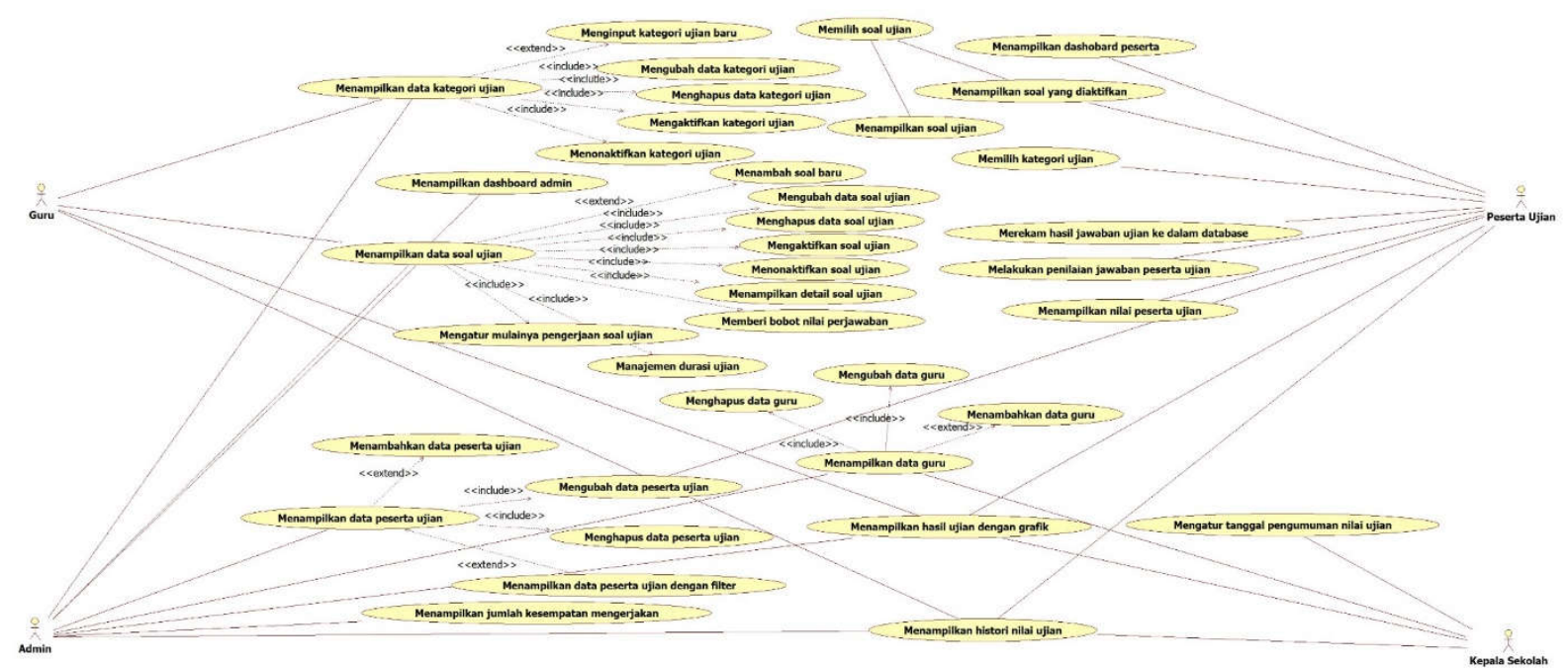

Gambar 2. Gambar Usecase Diagram

Pembuatan program adalah langkah pe-code-an dengan menggunakan bahasa pemrograman PHP dan dibantu dengan menggunakan Framework codeigniter sehingga dapat membuat sebuah website yang dapat dilihat pada gambar 3 merupakan halaman dashboard dari sistem.
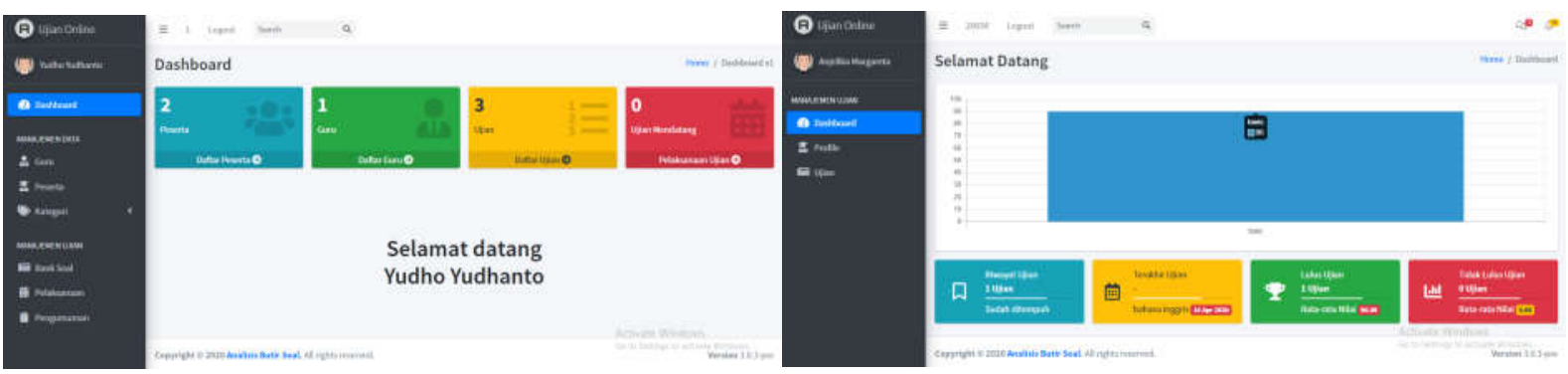

\section{Gambar 3. Gambar Halaman Dashboard}

Dapat dilihat bahwa hasil pengujian telah sesuai dengan perancangan pengujian, maka dapat dinyatakan berhasil. Pengujian fungsional keseluruhan dapat dilihat pada tabel 2 .

Tabel 2. Pengujian Fungsional

\begin{tabular}{|c|c|c|c|c|}
\hline No & Fungsionalitas & Skenario & Indikator & Status \\
\hline 1 & $\begin{array}{l}\text { Menampilkan } \\
\text { dashboard } \\
\text { admin }\end{array}$ & $\begin{array}{l}\text { a. Melakukan login } \\
\text { b. Sistem menampilkan dashboard } \\
\text { admin }\end{array}$ & $\begin{array}{l}\text { Admin dapat } \\
\text { melakukan login dan }\end{array}$ & Berhasi \\
\hline
\end{tabular}




\begin{tabular}{|c|c|c|c|c|}
\hline & & & $\begin{array}{l}\text { ditampilkan } \\
\text { dashboard admin }\end{array}$ & \\
\hline 2 & $\begin{array}{l}\text { Menampilkan } \\
\text { data kategori } \\
\text { ujian }\end{array}$ & $\begin{array}{l}\text { a. Memilih menu kategori ujian } \\
\text { b. Sistem menampilkan data kategori } \\
\text { ujian }\end{array}$ & $\begin{array}{l}\text { Ditampilkan data } \\
\text { kategori ujian }\end{array}$ & Berhasil \\
\hline 3 & $\begin{array}{l}\text { Menambah } \\
\text { kategori ujian } \\
\text { baru }\end{array}$ & $\begin{array}{l}\text { a. Memilih tombol tambah pada } \\
\text { tampilan data kategori ujian } \\
\text { b. Sistem menampilkan form tambah } \\
\text { kategori ujian } \\
\text { c. Mengisi form tambah kategori } \\
\text { ujian } \\
\text { d. Menyimpan data kategori ujian }\end{array}$ & $\begin{array}{l}\text { Data kategori ujian } \\
\text { yang baru tersimpan } \\
\text { ke dalam database }\end{array}$ & Berhasil \\
\hline 4 & $\begin{array}{l}\text { Mengubah data } \\
\text { kategori ujian }\end{array}$ & $\begin{array}{l}\text { a. Memilih aksi edit pada kategori } \\
\text { ujian yang akan diedit } \\
\text { b. Sistem menampilkan form edit } \\
\text { kategori ujian } \\
\text { c. Mengubah data kategori ujian } \\
\text { d. Menyimpan data kategori ujian }\end{array}$ & $\begin{array}{l}\text { Data kategori ujian } \\
\text { yang diubah, } \\
\text { berubah dalam } \\
\text { database }\end{array}$ & Berhasil \\
\hline 5 & $\begin{array}{l}\text { Menghapus data } \\
\text { kategori ujian }\end{array}$ & $\begin{array}{l}\text { a. Memilih aksi hapus pada kategori } \\
\text { ujian yang akan dihapus } \\
\text { b. Sistem menghapus data kategori } \\
\text { ujian }\end{array}$ & $\begin{array}{l}\text { Data kategori ujian } \\
\text { terhapus dari } \\
\text { database }\end{array}$ & Berhasil \\
\hline 6 & $\begin{array}{l}\text { Mengaktifkan } \\
\text { kategori ujian }\end{array}$ & $\begin{array}{l}\text { a. Memilih menu kategori ujian } \\
\text { b. Sistem menampilkan data kategori } \\
\text { ujian } \\
\text { c. Memilih tombol aktif }\end{array}$ & Kategori ujian aktif & Berhasil \\
\hline 7 & $\begin{array}{l}\text { Menonaktifkan } \\
\text { kategori ujian }\end{array}$ & $\begin{array}{l}\text { a. Memilih menu kategori ujian } \\
\text { b. Sistem menampilkan data kategori } \\
\text { ujian } \\
\text { c. Memilih tombol non aktif }\end{array}$ & $\begin{array}{l}\text { Kategori ujian non } \\
\text { aktif }\end{array}$ & Berhasil \\
\hline 8 & $\begin{array}{l}\text { Menampilkan } \\
\text { data soal ujian }\end{array}$ & $\begin{array}{l}\text { a. Memilih menu bank soal } \\
\text { b. Sistem menampilkan data ujian }\end{array}$ & $\begin{array}{l}\text { Ditampilkan data } \\
\text { soal ujian }\end{array}$ & Berhasil \\
\hline 9 & $\begin{array}{l}\text { Menambah soal } \\
\text { baru }\end{array}$ & $\begin{array}{l}\text { a. Memilih tombol tambah pada } \\
\text { tampilan data soal ujian } \\
\text { b. Sistem menampilkan form tambah } \\
\text { soal ujian } \\
\text { c. Mengisi form tambah soal ujian } \\
\text { d. Menyimpan data soal ujian }\end{array}$ & $\begin{array}{l}\text { Data soal ujian yang } \\
\text { baru tersimpan ke } \\
\text { dalam database }\end{array}$ & Berhasil \\
\hline 10 & $\begin{array}{l}\text { Mengubah data } \\
\text { soal ujian }\end{array}$ & $\begin{array}{l}\text { a. Memilih aksi edit pada data soal } \\
\text { ujian yang akan diedit } \\
\text { b. Sistem menampilkan form edit } \\
\text { soal ujian } \\
\text { c. Mengubah data soal ujian } \\
\text { d. Menyimpan data soal ujian }\end{array}$ & $\begin{array}{l}\text { Data soal ujian yang } \\
\text { diubah, berubah } \\
\text { dalam database }\end{array}$ & Berhasil \\
\hline 11 & $\begin{array}{l}\text { Menghapus data } \\
\text { soal ujian }\end{array}$ & $\begin{array}{l}\text { a. Memilih aksi hapus pada data soal } \\
\text { ujian yang akan dihapus } \\
\text { b. Sistem menghapus data soal ujian }\end{array}$ & $\begin{array}{l}\text { Data soal ujian } \\
\text { terhapus dari } \\
\text { database }\end{array}$ & Berhasil \\
\hline 12 & $\begin{array}{l}\text { Mengaktifkan } \\
\text { soal ujian }\end{array}$ & $\begin{array}{l}\text { a. Memilih menu soal ujian } \\
\text { b. Sistem menampilkan data soal } \\
\text { ujian } \\
\text { c. Memilih tombol aktif }\end{array}$ & Soal ujian aktif & Berhasil \\
\hline 13 & $\begin{array}{l}\text { Menonaktifkan } \\
\text { soal ujian }\end{array}$ & $\begin{array}{l}\text { a. Memilih menu soal ujian } \\
\text { b. Sistem menampilkan data soal } \\
\text { ujian }\end{array}$ & Soal ujian non aktif & Berhasil \\
\hline
\end{tabular}




\begin{tabular}{|c|c|c|c|c|}
\hline & & c. Memilih tombol non aktif & & \\
\hline 14 & $\begin{array}{l}\text { Menampilkan } \\
\text { detail soal ujian }\end{array}$ & $\begin{array}{l}\text { a. Memilih menu bank soal } \\
\text { b. Sistem menampilkan data ujian } \\
\text { c. Memilih aksi soal }\end{array}$ & $\begin{array}{l}\text { Tertampil detail soal } \\
\text { ujian }\end{array}$ & Berhasil \\
\hline 15 & $\begin{array}{l}\text { Menampilkan } \\
\text { data guru }\end{array}$ & $\begin{array}{l}\text { a. Memilih menu guru } \\
\text { b. Sistem menampilkan data guru }\end{array}$ & $\begin{array}{l}\text { Ditampilkan data } \\
\text { guru }\end{array}$ & Berhasil \\
\hline 16 & $\begin{array}{l}\text { Menambah data } \\
\text { guru }\end{array}$ & $\begin{array}{l}\text { a. Memilih tombol tambah pada } \\
\text { tampilan data guru } \\
\text { b. Sistem menampilkan form tambah } \\
\text { guru } \\
\text { c. Mengisi form tambah guru } \\
\text { d. Menyimpan data guru }\end{array}$ & $\begin{array}{l}\text { Data guru yang baru } \\
\text { tersimpan ke dalam } \\
\text { database }\end{array}$ & Berhasil \\
\hline 17 & $\begin{array}{l}\text { Mengubah data } \\
\text { guru }\end{array}$ & $\begin{array}{l}\text { a. Memilih aksi edit pada data guru } \\
\text { yang akan diedit } \\
\text { b. Sistem menampilkan form edit } \\
\text { guru } \\
\text { c. Mengubah data guru } \\
\text { d. Menyimpan data guru }\end{array}$ & $\begin{array}{l}\text { Data guru yang } \\
\text { diubah, berubah } \\
\text { dalam database }\end{array}$ & Berhasil \\
\hline 18 & $\begin{array}{l}\text { Menghapus data } \\
\text { guru }\end{array}$ & $\begin{array}{l}\text { a. Memilih aksi hapus pada guru } \\
\text { yang akan dihapus } \\
\text { b. Sistem menghapus data guru }\end{array}$ & $\begin{array}{l}\text { Data guru terhapus } \\
\text { dari database }\end{array}$ & Berhasil \\
\hline 19 & $\begin{array}{l}\text { Menampilkan } \\
\text { data peserta } \\
\text { ujian }\end{array}$ & $\begin{array}{l}\text { a. Memilih menu peserta } \\
\text { b. Sistem menampilkan data peserta }\end{array}$ & $\begin{array}{l}\text { Ditampilkan data } \\
\text { peserta }\end{array}$ & Berhasil \\
\hline 20 & $\begin{array}{l}\text { Menambah data } \\
\text { peserta ujian }\end{array}$ & $\begin{array}{l}\text { a. Memilih tombol tambah pada } \\
\text { tampilan data peserta } \\
\text { b. Sistem menampilkan form tambah } \\
\text { peserta } \\
\text { c. Mengisi form tambah peserta } \\
\text { d. Menyimpan data peserta }\end{array}$ & $\begin{array}{l}\text { Data peserta yang } \\
\text { baru tersimpan ke } \\
\text { dalam database }\end{array}$ & Berhasil \\
\hline 21 & $\begin{array}{l}\text { Mengubah data } \\
\text { peserta ujian }\end{array}$ & $\begin{array}{l}\text { a. Memilih aksi edit pada data } \\
\text { peserta yang akan diedit } \\
\text { b. Sistem menampilkan form edit } \\
\text { peserta } \\
\text { c. Mengubah data peserta } \\
\text { d. Menyimpan data peserta }\end{array}$ & $\begin{array}{l}\text { Data peserta yang } \\
\text { diubah, berubah } \\
\text { dalam database }\end{array}$ & Berhasil \\
\hline 22 & $\begin{array}{l}\text { Menghapus data } \\
\text { peserta ujian }\end{array}$ & $\begin{array}{l}\text { a. Memilih aksi hapus pada peserta } \\
\text { yang akan dihapus } \\
\text { b. Sistem menghapus data peserta }\end{array}$ & $\begin{array}{l}\text { Data peserta } \\
\text { terhapus dari } \\
\text { database }\end{array}$ & Berhasil \\
\hline 23 & $\begin{array}{l}\text { Menampilkan } \\
\text { data peserta } \\
\text { ujian dengan } \\
\text { filter }\end{array}$ & $\begin{array}{l}\text { a. Memilih menu peserta } \\
\text { b. Sistem menampilkan data peserta } \\
\text { ujian yang difilter }\end{array}$ & $\begin{array}{l}\text { Ditampilkan data } \\
\text { peserta dengan filter }\end{array}$ & Berhasil \\
\hline 24 & $\begin{array}{l}\text { Memberi bobot } \\
\text { nilai perjawaban }\end{array}$ & $\begin{array}{l}\text { a. Memilih menu bank soal } \\
\text { b. Sistem menampilkan data ujian } \\
\text { c. Memilih aksi soal } \\
\text { d. Sistem menampilkan data soal } \\
\text { ujian } \\
\text { e. Memilih tombol tambah } \\
\text { f. Sistem menampilkan form opsi } \\
\text { soal } \\
\text { g. Mengisi form opsi dengan } \\
\text { memberi bobot setiap jawaban } \\
\text { yang terdapat pada form opsi }\end{array}$ & $\begin{array}{l}\text { Ditampilkan bobot } \\
\text { nilai perjawaban } \\
\text { dalam setiap soal }\end{array}$ & Berhasil \\
\hline
\end{tabular}




\begin{tabular}{|c|c|c|c|c|c|}
\hline & & & $\begin{array}{l}\text { Menyimpan data bobot nilai } \\
\text { perjawaban }\end{array}$ & & \\
\hline & $\begin{array}{l}\text { Memanajemen } \\
\text { durasi ujian }\end{array}$ & a. & $\begin{array}{l}\text { Memilih tombol tambah pada } \\
\text { tampilan data pelaksanaan } \\
\text { Sistem menampilkan form } \\
\text { pelaksanaan } \\
\text { Mengisi form pelaksanaan dengan } \\
\text { memanajemen durasi ujian } \\
\text { Menyimpan data durasi ujian }\end{array}$ & $\begin{array}{l}\text { Ditampilkan durasi } \\
\text { ujian }\end{array}$ & Berhasil \\
\hline & $\begin{array}{l}\text { Mengatur } \\
\text { mulainya } \\
\text { pengerjaan soal } \\
\text { ujian }\end{array}$ & a. & $\begin{array}{l}\text { Memilih tombol tambah pada } \\
\text { tampilan data pelaksanaan } \\
\text { Sistem menampilkan form } \\
\text { pelaksanaan } \\
\text { Mengisi form pelaksanaan dengan } \\
\text { mengisi tanggal dan jam ujian } \\
\text { Menyimpan data mulainya } \\
\text { pengerjaan soal ujian }\end{array}$ & $\begin{array}{l}\text { Ditampilkan waktu } \\
\text { mulai pengerjaan } \\
\text { ujian }\end{array}$ & Berhasil \\
\hline 27 & $\begin{array}{l}\text { Menampilkan } \\
\text { jumlah } \\
\text { kesempatan } \\
\text { mengerjakan }\end{array}$ & a. & $\begin{array}{l}\text { Memilih tombol tambah pada } \\
\text { tampilan data pelaksanaan } \\
\text { Sistem menampilkan form } \\
\text { pelaksanaan } \\
\text { Mengisi form pelaksanaan dengan } \\
\text { mengisi mengisi jumlah } \\
\text { kesempatan } \\
\text { Menyimpan data mulainya } \\
\text { pengerjaan soal ujian } \\
\end{array}$ & $\begin{array}{l}\text { Ditampilkan jumlah } \\
\text { kesempatan } \\
\text { mengerjakan dalam } \\
\text { ujian }\end{array}$ & Berhasil \\
\hline 28 & $\begin{array}{l}\text { Menampilkan } \\
\text { dashboard } \\
\text { peserta }\end{array}$ & $\begin{array}{l}\text { a. } \\
\text { b. }\end{array}$ & $\begin{array}{l}\text { Melakukan login } \\
\text { Sistem menampilkan dashboard } \\
\text { peserta }\end{array}$ & $\begin{array}{l}\text { Peserta dapat } \\
\text { melakukan login dan } \\
\text { ditampilkan } \\
\text { dashboard peserta } \\
\end{array}$ & Berhasil \\
\hline 29 & $\begin{array}{l}\text { Menampilkan } \\
\text { soal yang } \\
\text { diaktifkan }\end{array}$ & $\begin{array}{l}\text { a. } \\
\text { b. }\end{array}$ & $\begin{array}{l}\text { Memilih menu ujian } \\
\text { Sistem menampilkan ujian yang } \\
\text { aktif }\end{array}$ & $\begin{array}{l}\text { Ditampilkan soal } \\
\text { ujian yang aktif }\end{array}$ & Berhasil \\
\hline 30 & $\begin{array}{l}\text { Memilih kategori } \\
\text { ujian }\end{array}$ & $\begin{array}{l}\text { a. } \\
\text { b. }\end{array}$ & $\begin{array}{l}\text { Memilih kategori ujain } \\
\text { Sistem menampilkan hasil } \\
\text { kategori ujian }\end{array}$ & $\begin{array}{l}\text { Ditampilkan kategori } \\
\text { ujian }\end{array}$ & Berhasil \\
\hline 31 & $\begin{array}{l}\text { Memilih soal } \\
\text { ujian }\end{array}$ & $\begin{array}{l}\text { a. } \\
\text { b. }\end{array}$ & $\begin{array}{l}\text { Memilih soal ujian } \\
\text { Sistem menampilkan soal ujian }\end{array}$ & $\begin{array}{l}\text { Ditampilkan soal } \\
\text { ujian }\end{array}$ & Berhasil \\
\hline 32 & $\begin{array}{l}\text { Menampilkan } \\
\text { soal ujian }\end{array}$ & $\begin{array}{l}\text { a. } \\
\text { b. }\end{array}$ & $\begin{array}{l}\text { Memilih soal ujian } \\
\text { Sistem menampilkan soal ujian }\end{array}$ & $\begin{array}{l}\text { Ditampilkan soal } \\
\text { ujian }\end{array}$ & Berhasil \\
\hline 33 & $\begin{array}{l}\text { Merekam hasil } \\
\text { jawaban ujian ke } \\
\text { dalam database }\end{array}$ & $\begin{array}{l}\text { a. } \\
\text { b. }\end{array}$ & $\begin{array}{l}\text { Memilih nomor soal } \\
\text { Sistem menampilkan butir soal } \\
\text { dan opsi } \\
\text { Memilih jawaban dan menekan } \\
\text { simpan jawaban }\end{array}$ & $\begin{array}{l}\text { Jawaban ujian } \\
\text { tersimpan ke dalam } \\
\text { database }\end{array}$ & Berhasil \\
\hline 34 & $\begin{array}{l}\text { Melakukan } \\
\text { penilaian } \\
\text { jawaban peserta } \\
\text { ujian }\end{array}$ & $\begin{array}{l}\text { a. } \\
\text { b. }\end{array}$ & $\begin{array}{l}\text { Melakukan submit selesai ujian } \\
\text { Sistem mengkalkulasi nilai } \\
\text { jawaban } \\
\text { Sistem menampilkan nilai ujian }\end{array}$ & $\begin{array}{l}\text { Ditampilkan nilai } \\
\text { peserta ujian }\end{array}$ & Berhasil \\
\hline 35 & $\begin{array}{l}\text { Mengatur } \\
\text { tanggal } \\
\text { pengumuman } \\
\text { nilai ujian }\end{array}$ & a. & $\begin{array}{l}\text { Memilih tombol tambah pada } \\
\text { tampilan data pengumuman } \\
\text { Sistem menampilkan form } \\
\text { pengumuman }\end{array}$ & $\begin{array}{l}\text { Ditampilkan data } \\
\text { pengumuman nilai } \\
\text { ujian }\end{array}$ & Berhasil \\
\hline
\end{tabular}




\begin{tabular}{cllll}
\hline C. $\begin{array}{l}\text { Mengisi form pengumuman nilai } \\
\text { ujian }\end{array}$ & & \\
& d. Menyimpan data pengumuman \\
nilai ujian & $\begin{array}{l}\text { Menampilkan } \\
\text { nilai peserta } \\
\text { ujian }\end{array}$ & $\begin{array}{l}\text { a. Memilih menu pengumuman } \\
\text { b. Sistem menampilkan } \\
\text { pengumuman dan nilai ujian }\end{array}$ & $\begin{array}{l}\text { Ditampilkan nilai } \\
\text { peserta ujian }\end{array}$ & Berhasil \\
\hline 37 & $\begin{array}{l}\text { Menampilkan } \\
\text { hasil ujian } \\
\text { dengan grafik }\end{array}$ & $\begin{array}{l}\text { a. } \text { Memilih menu dashboard } \\
\text { b. Sistem menampilkan hasil ujian } \\
\text { yang sudah diumumkan }\end{array}$ & $\begin{array}{l}\text { Ditampilkan grafik } \\
\text { hasil ujian }\end{array}$ & Berhasil \\
\hline 38 & $\begin{array}{l}\text { Menampilkan } \\
\text { histori nilai ujian }\end{array}$ & $\begin{array}{l}\text { a. } \text { Memilih riwayat ujian } \\
\text { b. Sistem menampilkan riwayat ujian }\end{array}$ & $\begin{array}{l}\text { Ditampilkan histori } \\
\text { nilai ujian }\end{array}$ & Berhasil \\
\hline
\end{tabular}

\section{KESIMPULAN}

Penelitian yang dilakukan telah berhasil merancang dan membangun Aplikasi Exam Dengan Metode Analisis Butir Soal sebagai berikut:

1. Terdiri dari empat aktor yaitu admin, guru, kepala sekolah, dan peserta ujian.

2. Sistem ini dapat memudahkan guru mengetahui tingkat kesulitan soal yang dikerjakan peserta ujian, serta memudahkan peserta ujian melihat informasi hasil ujian lulus atau tidak berdasarkan nilai yang diperoleh sebagai acuan untuk mengerjakan soal ujian ulang.

\section{UCAPAN TERIMA KASIH}

Kami ucapkan terimakasih pada semua pihak yang mendukung penelitian ini yaitu semua keluarga Sekolah Vokasi Universitas Sebelas Maret terutama Program Studi D3 Teknik Informatika.

\section{REFERENSI}

[1] Abdul. 2019. Pengguna Internet Tembus 175 Juta. Retrieved from Investor Daily: https://investor.id/archive/2019-pengguna-internet-tembus-175-juta

[2] Anggy Trisnawan Putra. 2018. Rancang Bangun Aplikasi Ujian Online Berbasis Web. Ilmu Komputer, Fakultas Matematika dan IImu Pengetahuan Alam. Indonesia: Universitas Negeri Semarang.

[3] Wisnu Wardoyo dan Eko Suprapto. Rancang Bangun Program Analisis Butir Soal Pilihan Ganda Sebagai Pendukung Proses Evaluasi Pembelajaran. Teknik Elektro, Fakultas Teknik. Semarang, Indonesia: Universitas Negeri Semarang.

[4] Muhammad Dwika llyas Ruhyat. 2019. Rancang Bangun Aplikasi Ujian Online Untuk Siswa SMP Menggunakan Framework Laravel (Studi Kasus : Smp Negeri 4 Cikalongkulon). Teknik Informatika, Fakultas Teknik. Indonesia: Universitas Pasundan Bandung.

[5] Dewa Ayu Sri Agustina. 2017. Perancangan Aplikasi Computer Based Test (Cbt) Berbasis Web (Studi Kasus Di SMP Negeri 2 Kuta - Badung). Teknik Informatika, Fakultas IImu Kesehatan Sains dan Teknologi. Indonesia: Universitas Dhayana Pura Bali.

[6] Endri Rahmawanto. 2015. Sistem Informasi Ujian Mandiri Online Berbasis Web Di SMP Negeri 1 Srandakan. Teknik Informatika, Fakultas Teknologi Industri. Indonesia: Universitas Ahmad Dahlan Yogyakarta. 